\title{
Ectopic prostatic tissue in the perineum
}

\author{
Bishoy Hanna (1) , ${ }^{1,2}$ Anna McNaught, ${ }^{3}$ Amanda Chung, ${ }^{1,4,5}$ Venu Chalasani ${ }^{1,5,6}$
}

'Department of Urology, Northern Beaches Hospital, Frenchs Forest, New South Wales, Australia

${ }^{2}$ Department of Urology, Nepean Urology Research Group, Kingswood, New South Wales, Australia ${ }^{3}$ Department of Radiology, Royal North Shore Hospital, St Leonards, New South Wales, Australia

${ }^{4}$ Department of Urology, Macquarie University Hospital, Macquarie University, New South Wales, Australia ${ }^{5}$ Department of Urology, Royal North Shore Hospital, St Leonards, New South Wales, Australia

${ }^{6}$ Department of Urology, The University of Sydney, Camperdown, New South Wales, Australia

Correspondence to Dr Bishoy Hanna;

bishoy.hanna@icloud.com

Accepted 8 October 2020

\section{DESCRIPTION}

Ectopic prostatic tissue is rare and $<50$ cases have been reported in the literature. The most common reported location is the trigone of the urinary bladder and rarely at the bladder neck or periurethral location. ${ }^{1}$ Postulated aetiology of prostatic ectopia include the persistence of prostatic tissue during embryogenesis, or metaplasia of the urinary epithelium due to chronic inflammation, or even migration of prostatic stem cells. ${ }^{2-4}$

We present a 72-year-old man with a 1-week history of progressively worsening obstructive lower urinary tract symptoms culminating in overt acute urinary retention of $>1 \mathrm{~L}$. This was acutely managed with an indwelling catheter. His medical history included hypertension and gastro-oesophageal reflux. His international prostate symptom score was 6 prior to the onset of symptoms, and a digital rectal examination revealed a mildly enlarged benign prostate. The prostate-specific antigen (PSA) was $7.0 \mu \mathrm{g} / \mathrm{L}$. MRI of the prostate showed Prostate Imaging Reporting And Data Systems 3 lesions along with a solid lesion distal to the prostatic apex in the midline, completely separate from the prostate (figure 1). This lesion was smooth, well circumscribed and appeared benign. A cystoscopy revealed no intraluminal urethral lesions with a mildly enlarged, non-occlusive prostate and unremarkable bladder. The patient underwent a systematic transperineal prostate biopsy with additional cores taken corresponding to the extraprostatic perineal lesion on MRI. Histopathology showed benign prostatic hyperplasia of the extraprostatic perineal lesion and Grade Group 2 adenocarcinoma within the prostate.

Ectopic prostatic tissue has been described widely throughout the body, most commonly in the urethra, seminal vesicles, epididymis, testis and urinary bladder. ${ }^{5-10}$ Clinically, they present with lower urinary tract symptoms; haematuria being most common but obstructive symptoms such
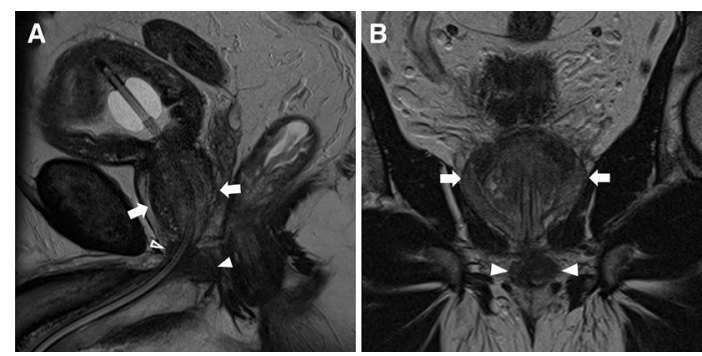

Figure $1 \mathrm{MRI}$ of the prostate with $(\mathrm{A})$ sagittal $\mathrm{T} 2$ weighted (T2W) and (B) coronal T2W images showing the prostate gland (solid arrows), ectopic prostate tissue (solid arrowhead) and urethral sphincter (open arrowhead).

\section{Learning points}

- Ectopic prostate tissue (EPT) distal to the apex of the prostate is a rare entity, as it is commonly located on the trigone of the bladder.

- MRI is a sensitive imaging modality for detecting EPT.

- It may be a rare cause of persistently raised prostate-specific antigen following a radical prostatectomy.

- It should be considered in the differential diagnosis of a palpable lump on digital rectal examination.

as urinary frequency and retention also feature. Outside of the genitourinary system, ectopic prostatic tissue is a distinctly uncommon phenomenon but has been reported in the spleen, rectum and uterine cervix, as well as in ovarian teratomas. ${ }^{11-13}$

Various aetiologies have been postulated for ectopic prostate tissue. In the prostatic urethra and bladder trigone, this may represent a vestigial remnant from embryogenesis, while for other sites metaplasia and aberrant embryogenesis via 'migration' or 'misplacement' of prostate glands have been described. 1012

Generally if the lesion is asymptomatic and benign, resection is not indicated. However, it should be noted that this tissue will be a source of PSA. Primary adenocarcinoma arising from ectopic prostatic tissue has been reported. ${ }^{1415}$ A 5 -mm cystic bladder lesion was found to be prostatic adenocarcinoma on resection (Gleason $4+3=7) .{ }^{14}$ Furthermore, a report of ectopic prostate cancer (Gleason $4+3=7$ ) in the seminal vesicles surrounded by normal prostatic glands with a transrectal prostate biopsy showing no intraprostatic cancer was managed with radiotherapy and hormonal treatment. ${ }^{15}$ Ectopic prostatic tissue is a rare entity but significant as it may be a site for primary prostate cancer and will cause a persistently raised PSA following a radical prostatectomy.

Contributors BH: primary author who gathered the relevant information for the case, reviewed the literature and wrote the manuscript. Furthermore, he coordinated input from the rest of the research team for revisions and submission. AMN: provided valuable insights on the radiological images ensuring suitable quality and accurate interpretation. Furthermore, she was involved in reviewing the final manuscript. AC: provided valuable insights on the case, including the up to date evidence in the area, and reviewed the manuscript. VC: the primary clinician for the patient at the centre of the case. He gathered, interrupted case material and reviewed the manuscript.

Funding The authors have not declared a specific grant for this research from any funding agency in the public, commercial or not-for-profit sectors. 
Images in...

Competing interests None declared.

Patient consent for publication Obtained.

Provenance and peer review Not commissioned; externally peer reviewed.

\section{ORCID iD}

Bishoy Hanna http://orcid.org/0000-0002-1463-9644

\section{REFERENCES}

1 Bellezza G, Sidoni A, Cavaliere A. Ectopic prostatic tissue in the bladder. Int J Urol 2005:12:1066-8.

2 Delladetsima J, Theodorou C, Dapolla Y, et al. Prostatic-type epithelium in urinary bladder. Clinical, histologic, and immunohistochemical study. Urology 1990;36:445-8.

3 Dogra PN, Ansari MS, Khaitan A, et al. Ectopic prostate: an unusual bladder tumor. Int Urol Nephrol 2002;34:525-6.

4 Fulton RS, Rouse RV, Ranheim EA. Ectopic prostate: case report of a presacral mass presenting with obstructive symptoms. Arch Pathol Lab Med 2001;125:286-8.

5 Leifert S, Lurie A, Kellner J. Ectopic prostatic tissue in urethra. Urology 1985;26:509-10.

6 Lau SK, Chu PG. Prostatic tissue ectopia within the seminal vesicle: a potential source of confusion with seminal vesicle involvement by prostatic adenocarcinoma. Virchows Arch 2006:449:600-2
7 Bromberg WD, Kozlowski JM, Oyasu R. Prostate-type gland in the epididymis. J Urol 1991;145:1273-4.

8 Milburn JM, Bluth El, Mitchell WT. Ectopic prostate in the testicle: an unusual cause of a solid testicular mass on ultrasonography. J Ultrasound Med 1994;13:578-80.

9 Morey AF, Kreder KJ, Wikert GA, et al. Ectopic prostate tissue at the bladder dome. J Urol 1989;141:942-3.

10 Gardner JM, Khurana H, Leach FS, et al. Adenocarcinoma in ectopic prostatic tissue at dome of bladder: a case report of a patient with urothelial carcinoma of the bladder and adenocarcinoma of the prostate. Arch Pathol Lab Med 2010;134:1271-5.

11 Vogel U, Negri G, Bültmann B. Ectopic prostatic tissue in the spleen. Virchows Arch 1996;427:543-5.

12 Nucci MR, Ferry JA, Young RH. Ectopic prostatic tissue in the uterine cervix: a report of four cases and review of ectopic prostatic tissue. Am J Surg Pathol 2000;24): :1224-30.

13 McLachlin CM, Srigley JR. Prostatic tissue in mature cystic teratomas of the ovary. Am J Surg Pathol 1992;16:780-4.

14 Backhouse A, Vasilaras A, Yung T, et al. Adenocarcinoma arising within ectopic prostatic tissue in the urinary bladder. Pathology 2014:46:655-7.

15 Somwaru AS, Alex D, Zaheer A. Prostate cancer arising in ectopic prostatic tissue within the left seminal vesicle: a rare case diagnosed with multi-parametric magnetic resonance imaging and magnetic resonance imaging-transrectal ultrasound fusion biopsy. BMC Med Imaging 2016;16:16.

Copyright 2020 BMJ Publishing Group. All rights reserved. For permission to reuse any of this content visit https://www.bmj.com/company/products-services/rights-and-licensing/permissions/ BMJ Case Report Fellows may re-use this article for personal use and teaching without any further permission.

Become a Fellow of BMJ Case Reports today and you can:

- Submit as many cases as you like

- Enjoy fast sympathetic peer review and rapid publication of accepted articles

- Access all the published articles

- Re-use any of the published material for personal use and teaching without further permission

Customer Service

If you have any further queries about your subscription, please contact our customer services team on +44 (0) 2071111105 or via email at support@bmj.com.

Visit casereports.bmj.com for more articles like this and to become a Fellow 